\title{
A journey, I mean, a journal...
}

A journey of a thousand miles begins with a single step. Mao Zedong

Frustration and fear of failure are crippling burdens that can discourage one from taking the first step on a yet unchartered course. This might explain why it must have been a daunting task to launch this journal in 1996 at a time fraught with risks and red herrings. The Furquins and their enthusiastic team embarked on the dream of building a legacy meant to fill Brazilian orthodontists with pride. Despite the drawbacks, the first step was taken. It was high time for some of the world's most widely respected orthodontic professionals to prove their mettle and glimpse a horizon far beyond the fences that restrained them.

No matter how thick a forest, every road begins with a humble path being blazed across the vegetation. The first intrepid trailblazers ventured deep into the forest oblivious of obstacles both known and unknown. The dreams and the courage of Daniel Boone in the U.S. and the Villas Bôas brothers in Brazil, are extolled. Why not the Furquins? All these visionaries could plainly see the threat of failure looming, but with feet planted firm on the ground. Time ticks away inexorably and there comes a time when either the forest closes back in or a path is blazed to provide for passage and communication. Little by little, step by step, the path gets longer and longer while the trailblazer picks up a lively pace.

In Maringá, the first pioneering gesture to confront this huge challenge also began with a mere trail in the heart of a pine forest. It was there and then that the Dental Press journal of orthodontics, albeit limited by its own inexperience, emerged with the height of a pine tree in its ideological aspirations. The pathway opened in the jungle of the unknown was celebrated as a milestone. It was a narrow trail, overgrown with thorns, but determined not to perish.
Man (homo) is made out of "humus," (earth), said Nietzsche, and therefore, greater than man himself is his work. Should these men be ready for prosperity, they will be able to prepare disciples of their very same caliber. In 2003, Adilson Ramos, a young, extremely competent and humble professional - to a fault, even - brilliantly carried on the torch of his predecessor. Adilson's branches ('ramos' in Portuguese) grew forth and reached the remote Amazon. In 2005, when I received a letter of invitation to be a reviewer, an honor for this native Amazonian, Adilson expanded the means of delivery and shifted the axis of orthodontic geography in Brazil. With this gesture we had not just a trail, but a dichotomy on Terra Brasilis. The metaphorical road received finishing touches and the SciELO "seal." The journey on this road led to the "Dental Press Journal of Orthodontics and Dentofacial Orthopedics," which became the first specialized Brazilian journal indexed in this very important database along with three other multidisciplinary journals. At that moment the whole world would know it, admire it, and even applaud it.

In 2007, another passerby took to the road and was invited to carry on the management of the work. I must confess that at the time he was a stranger to me, as well I may be a stranger to you today: A lowly backpacker, to many readers. The painstaking "engineer" Faber, with his ubiquitous "niemeyerians" - among many other virtues - dared to dream dreams which some may label as reveries. To be a dreamer and yet meticulous may seem paradoxical. Nevertheless, if you look around you will see great works built by so many Quixotes. Brasília, his homeland, is an example of superb planning. We are happiest when we believe in our own dreams, because the art and action that 
go into them bring us closer to the Creator. And much more so when the act of creation is devoid of any futile interest for it is better to enjoy the simple pleasure derived from collaborating and growing exponentially than to idle about in quiet desperation waiting for Godot to sort out one's life. For all, "work" preceded "luck".

Jorge - that's how I fondly call him — paved the way for us by applying international publishing standards. Articles are now submitted online, and the journey, I mean, the journal crossed the boundaries of this vast country to embrace another language:-Yes, we don't have just bananas. Now, we are the Dental Press Journal of Orthodontics. Meanwhile, I was invited to occupy the position of assistant editor. So I introduced myself to someone who was only able to recognize me by looking at me askance. And I realize that in today's Brasilia there are men who remind us of some of the great souls who helped to conceive it. Maringá joined Brasilia on that road that could well serve as a nostalgic example for the entire country. Now, the Belém-Brasilia highway in its colossal dimensions and its careful planning epitomizes the pioneering spirit of those who built it almost the size of Brazil.

The journal, I mean, the journey on this road, now paved, signalized and expanded, so pretty and so well built, became the first pathway of our researchers and readers. But all is not peaches and cream: An avalanche of papers congested the editorial traffic, which can be distressing to an editor. Good articles seek publication, but there is a limit even to a(n) (in) commensurate space. The group of road engineers, i.e., editors - relying on the (inter)national competence of Daniela Garib (USP/Bauru-SP), Matheus Pithon (UESB/BA), Flavia Artese (UERJ), Fernanda Angelieri (USP-SP),
Ildeu Andrade Jr. (PUC-MG) and the tireless Telma Martins (UFBA) — is forced to set three parasympathetic goals: Increase the number of online articles, reduce the size of the texts, and the inevitable and painful rejection of good articles. Whenever we say "no" we must stop and consider who is the target of this negative answer. They are often young folks striving to take their dreams to the next level: Sometimes Science is the irrational side of our dreams.

Thus, I am simply delighted to share with you some episodes in the history of this journal. I would also like to extend a heart-felt thank you to those friends who traveled with me along each and every highway: Laurindo and Teresa, Adilson and Jorge, for the presage they conceived and for sprinkling their holy water on me. Furthermore, to the editors and reviewers for sticking with us through this transition. Our duty consists simply in maintaining the quality of the work. Hopefully, there should be no further claims. However, if only I could trick the infamous "regression to the mean" and raise it to the pinnacle of my dreams, I would have, metaphorically, the following: All holes duly filled, a preserved signage and a smoother traffic control. In this case, not regressing would in itself mean progress for those with the challenging mission of maintaining the excellent level of the road where our journey, I mean, journal, is transporting us. After all, Science owes much to statisticians, but is also built by dreamers, who dare to dream and endure the pangs of creation.

Finally, let us move on...

And good reading!

David Normando

Editor-in-chief davidnor@amazon.com.br 